\title{
O NEPEC COMO LUGAR DE RESSIGNIFICAÇÃO DO PENSAR GEOGRÁFICO
}

- IVO FRANCISCO BARBOSA ${ }^{1}$

1 Doutorando em Geografia na Universidade Estadual do Rio de Janeiro. E-mail para contato: ivo_francisco@hotmail.com

Recebido em:10/07/2020

Aprovado em: 22/01/2021

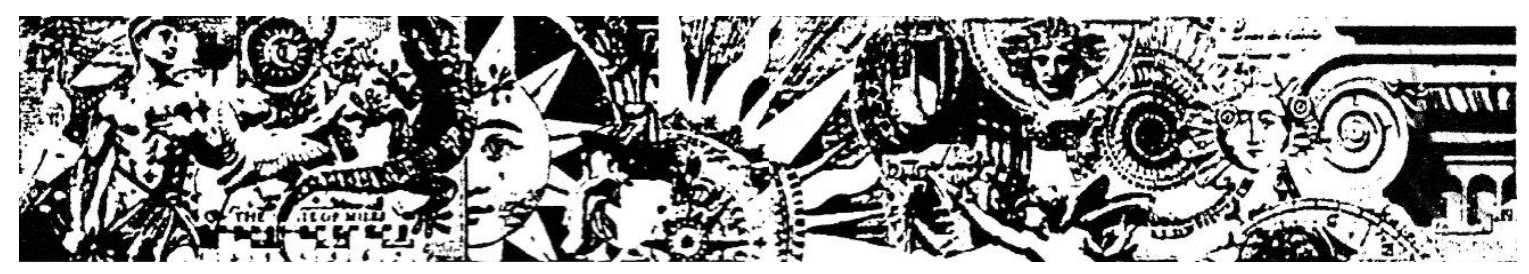

A Revista Espaço e Cultura completa 25 anos de existência, com destaque reconhecido na ciência geográfica na tradução de artigos e resenhas de pesquisadores estrangeiros e, também, com a participação de pesquisadores brasileiros. Sua importância advém, principalmente, do seu papel na difusão do conhecimento, na divulgação do saber sob a perspectiva cultural no campo de pesquisa geográfico. Nosso depoimento passa pelo primeiro contato com o seu núcleo de pesquisa, o lugar NEPEC. Pois, pensamos como considera Santos (1988), cada lugar possui um tempo espacial próprio que não se repete em outro e este está condicionado, conforme Corrêa (1987), a ações específicas da localidade. Pensando nessa possibilidade, dividiremos nosso relato em dois momentos: a) a chegada ao NEPEC e a sua importância na construção do conhecimento geográfico deste pesquisador e de sua pesquisa; e b) a participação como membro editorial da Revista Espaço e Cultura.

O nosso ponto de partida, o tempo espacial próprio, se dá com o início do doutorado em Geografia sobre a orientação da professora Dr ${ }^{\mathrm{a}}$ Zeny Rosendahl, mais 
especificamente no NEPEC - Núcleo de Pesquisa Espaço e Cultura. Os primeiros momentos não dimensionavam a compreensão do que é o lugar NEPEC e a Revista Espaço e Cultura. A percepção que: a) Rosendahl, b) o NEPEC e c) o periódico não são vistos de maneira separada ocorreu com a participação na disciplina Cultura e Natureza em 2017. A compreensão da importância dos estudos da geografia cultural para a ciência geográfica atual começou a ser demarcada a partir daquele instante. Ali, o entendimento do que é a temática da geografia cultural no Brasil extrapolaram os livros, bem como da criadora, sua pesquisa e os trabalhos que compõem o acervo. Os referenciais passaram a integrar uma valorosa (res)significação da pesquisa de doutoramento.

O NEPEC corresponde o lugar de diálogo, de vivências e de interpretações, lugar onde o pensar afetivo se insere como elemento constituinte do interpretar geográfico. É neste lugar que, fisicamente, a Revista Espaço e Cultura se encontra, onde livros, teses, dissertações, exemplares do periódico, símbolos, objetos, alunos, professores, pesquisadores - pessoas - pensam a geografia cultural da UERJ e do Brasil. O NEPEC é e sempre será um lugar de encontros e conversas, um ambiente valioso para a comunicação e receptível para o estrangeiro. Lá me senti em casa em todos os momentos, acolhido.

O iniciar no NEPEC e a orientação de Zeny Rosendahl impulsionaram uma nova intepretação do fenômeno religioso e sua espacialidade. São reconhecidos pelas pesquisas temáticas da religião, que na geografia brasileira ganham relevância a partir da década de 1990, com os estudos relacionados à dimensão espacial da religião católica, a partir da tese de Zeny Rosendahl apresentada em 1994 na Universidade de São Paulo (USP). Esta forma de pensar geográfico é carinhosamente apelidado Rosendahliano por seus orientandos, uma maneira de tornar inteligível a espacialidade do sagrado e do profano no campo geográfico, uma maneira de pensar para além do academicismo, uma maneira de ser, ver, sentir e viver os lugares - que está no lugar NEPEC/Zeny Rosendahl.

Nosso segundo momento do depoimento diz respeito à compreensão da relevância da Revista Espaço e Cultura para a geografia brasileira e mundial. Tive o prazer, juntamente com o corpo editorial, de diagramar alguns artigos que iriam integrar as edições lançadas em 2017, num período que ficou marcado por sucessivos cortes financeiros nas universidades brasileiras e descrédito da ciência como um todo. Embora todo o cenário adverso, a revista se manteve ativa e no esforço do seu núcleo, os exemplares foram lançados. Tal experiência confirmou a importância e alcance do periódico, a riqueza da pesquisa na geografia cultural brasileira e no exterior, as 
pluralidades temáticas, os diversos pesquisadores que ali estiveram, a resistência do campo temático e a percepção dos caminhos trilhados até então e os que serão traçados no futuro. A Revista Espaço e Cultura é a consolidação do pensar da geografia cultural, ela é o NEPEC e a professora Dra Zeny Rosendahl, mas também é daqueles que passaram, ajudam e acreditam numa geografia multifacetada e polissêmica. Ela é pesquisa e ciência, é geografia brasileira.

\section{REFERÊNCIAS BIBLIOGRÁFICAS}

CORREAA, R.L. A periodização da Rede Urbana da Amazônia. Revista Brasileira de Geografia, 49/3, pp. 39-68, 1987.

SANTOS, M. Metamorfoses do espaço habitado. São Paulo: Hucitec, 1988. 